Volume 8 No. 2, Juli-Desember 2021

P-ISSN: 2406-808X // E-ISSN: 2550-0686

https://journal.iainlangsa.ac.id/index.php/ikhtibar

https://doi.org/10.32505/ikhtibar.v8i2.630

\title{
Manajemen Pendidikan Dalam Bingkai Otonomi Daerah Analisis Terhadap Sistem Pendidikan di Daerah
}

\author{
Mulyadi Ibrahim \\ IAIN Langsa \\ ${ }^{1}$ mulyaibr@gmail.com ${ }^{2}$ mulyadi@iainlangsa.ac.id
}

\begin{abstract}
Abstrak
Mengingat luasnya wewenang yang diberikan pemerintah pusat terhadap daerah dalam mengelola pendidikan sehingga banyak menimbulkan masalah khususnya dalam mengimplementasikan undang-undang No. 22 Tahun 1999. Ini menunjukan bahwa urusan pendidikan diserahkan kepada daerah dan daerah memiliki wewenang penuh dalam mengatur dan mengelola pendidikan yang ada di daerahnya, apakah ia pendidikan dasar maupun ke perguruan tinggi. Kendatipun demikian apakah benar pelaksanaannya sesuai dengan amanah undang-undang? Justru yang terjadi adalah sebaliknya. Masalah ini muncul terutama pada pendidikan tinggi terus beranggapan bahwa pemerintah daerah tidak ada wewenang dan mempunyai hak terhadap menajemen pendidikan tinggi, sehingga daerah tidak memperdulikan sama sekali terhadap keberlangsungan pendidikan tinggi. seharusnya daerah harus paham betul dengan adanya otonomi daerah maka otonomi pendidikan menjadi sebuah keniscayaan bagi daerah.
\end{abstract}

Keyword: Manajemen Pendidikan, Otonomi Daerah.

\section{A. Pendahuluan}

Pada dasarnya pendidikan merupakan suatu proses untuk mengangkat harkat dan martabat seseorang dengan sengaja dan sadar diuapayakan terus menerus. Dalam proses ini terjadi menunjukkan bahwa pendidikan mempunyai nilai-nilai, dogma dan kreatifitas, karena jika kita berbicara pendidikan pada hakekatnya membicarakan harkat dan martabat serta nilai-nilai kemanusiaan. Tidak ada perbedaan yang mencolok dalam memaknai fungsi dan tujuan pendidikan agama Islam dimana fungsi pendidikan yaitu untuk pengembangan diri seseorang, penyaluran peserta didik untuk memiliki bakat khusus, sebagai perbaikan seseorang, sebagai pencegahan dari hal-hal negatif, sebagai penyesuaian dengan lingkungan maupun sosial dan menjadi sumber atau pedoman kehidupan ( Ramayulis, Metodologi Pendidikan Agama Islam: 2008. 21).

Dalam perkembangannya, pendidikan dijadikan sebagai sebuah ilmu yang didalamnya terdapat berbagai macam metode yang harus dipelajari dan dikembangkan secara terus menerus dan mengikuti perkembangan zaman. Untuk menyebar luaskan konsep keilmuan dipelukan lembaga baik formal ( resmi ) ataupun informal dan untuk menggerakkannya maka dibutuhkan manajemen supaya proses proses pengembangan keilmua itu tercapai tujuannya sesuai dengan harapan dan citacita bangsa dan negara.

Berbicara tentang sistem pendidikan tentu tidak hanya melihat pada sisi administrasinya saja tetapi lebih daripada itu semua yang berkaitan dengan 
pendidikan harus dilihat dan dirancang secara sistematis. Apabila manjemen pendidikan dipandang sebagai administrasinya saja maka akibatnya, paradigma pendidikan yang universal dipandang secara sempit, dan lebih banyak adaptif daripada inisiatif. Sistem administrasi pendidikan lebih banyak tergantung pada sistem politik dalam menyelenggarakan tatanan negara saja dan penyelenggaraan pendidikan masih diatur oleh pusat sehingga sulit untuk mengembangkan pendidikan yang dikaitkan dengan otonomi daerah.

Asumsi tentang sistem pendidikan seperti itu tidaklah mengherankan karena memang beranjak dari asumsi yang sempit pula. Namun, upaya pendidikan yang didasari asumsi seperti itu, tidak cukup membawa bangsa ini ke arah tujuan-tujuan pendidikan yang universal. Gejala disintegrasi bangsa, degradasi moral, korupsikolusi-nepotisme, diakui atau tidak, merupakan sebagian dari kegagalan-kegagalan yang dicapai proses pendidikan selama ini. Karena itu, memahami sistem pendidikan nasional tidak sekedar latah karena alasan-alasan politis, dan selalu tergantung pada situasi politik kenegaraan.

Akibat tidak adanya kesepahaman dan terminologi inilah menjadikan pandangan terhadap manajemen (administrasi) pendidikan dalam konteks otonomi daerah tidak kunjung selesai. Dan manakala kebijakan penyelenggaraan pendidikan menjadi otoritas pada Pemerintah Pusat, menunjukan bahwa pada hakekatnya penyelenggaraan pendidikan yang universal semakin sempit dalam arti persekolahan. Dan praktek manajemen pendidikan pada level pusat, regional, lokal dan kelembagaan pun menjadi sarana pencapaian tujuan politik yang diarahkan pada reproduksi ideologi kelompok yang dominan. Dengan sistem manajemen seperti itu, berdampak pula pada para ilmuwan dan cendikiawan yang ide-ide, konsep, teori yang tidak relevan dengan tujuan-tujuan tersebut. Diakui, bahwa pendidikan tidak bebas nilai dan tidak juga bebas budaya. Pendidikan nasional memang diarahkan pada pembentukan warga negara, dan karena itulah pendidikan menjadi tanggung jawab semua komponen bangsa. Namun otonomi masing-masing komponen itulah perlu dipertegas. Sebatas mana kewenangan diberikan kepada pihak keluarga, masyarakat dan pemerintah? Di sektor pemerintah, sebatas mana kewenangan manajemen pendidikan diserahkan dari tingkat pusat ke pemerintah tingkat regional, lokal sampai ke tingkat kelembagaan?

Artikel ini mencoba mengangkat isu tentang manajemen pendidikan dalam bingkai otonomi daerah, dengan maksud mendapat gambaran yang lebih komprehensif tentang prospek otonomi dalam dunia pendidikan.

\section{B. Pembahasan}

\section{Manajemen Pendidikan}

Dilihat dari istilah pengertian manejemen sangat beragam seabagaimana yang dikemukana oleh Uhar Suharsaputra dalam Administrasi Pendidikan yang dikutip dari berbagai ilmuan diantaranya adalah a). oleh Lester Robert Bittel " The most comprehensive definition views management as an integrating process by wich outhorized individual create, maintain, and operate an organization in the selection an accomplishment of it's aims. ". b). Prajudi atmosudirdjo " Manajmen itu adalah pengendalian dan pemamfaatan semua faktor dan sumberdaya, yang menurut suatu perencanaan, diperlukan untuk mencapai atau menyelesaikan suatu prapta atau tujuan kerja yang tertentu. c). Boone dan Kurtz " Manajemen is the use of people and other resources to accomplish objective ". d). Harold Koontz, Cyril O'Donnel " Management the function of getting thing done through people ". e). Sondang P.Siagian " Manejemen dapat didefenisikan sebagai kemampuan atau keterampilan untuk memperoleh suatu hasil dalam rangka pencapain tujuan melalui kegiatankegiatan orang lain, dengan demikian dapat pula dikatakan menejemen merupakan 
alat pelaksana utama administrasi ". ( Uhar Suharsaputra, Administrasi Pendidikan. 2013: 5-6 ). Selanjutnya Ricky W. Griffin dikutip oleh Subeki Ridhotullah dan Muhammad Jauhari dalam Pengantar Manajemen menjelaskan bahwa " manejemen adalah sebuah proses perencanaan, pengorganisasian, dan pengontrolan sumber daya untuk mencapai sasaran secara efektif san efesien. (Subeki Ridhotulah dan Muhammad Jauhar, Pengantar Manejemen. 2015: 1).

Bila dikaitkan dengan pendidikan maka manejemen pendidikan adalah suatu kegiatan yang menggabungkan sumber-sumber pendidikan agar terpusat dalam usaha mencapai tujuan pendidikan yang telah ditentukan sebelumnya dimana kepala sekolah bisa berperan sebagai administrator dalam mengemban misi atasan, sebagai manejer dalam memadukan sumber-sumber pendidikan dan juga berperan sebagai supervisor dalam membina guru-guru pada proses belajar mengajar. (Made Pidarta, Manajemen Pendidikan Indonesia. 2004: 2). Secara khusus H.A.R. Tilar menjelaskan bahwa yang dimaksud dengan manajemen Pendidikan adalah penerapan prinsip-prinsip manajemen dalam mengelola praksis pendidikan agar efektif dan efesien sehingga output dari organisasi pendidikan mempunyai mutu yang tinggi. (H.A.R.Tilar: Kekuasaan Dan Pendidikan; Manajemen Pendidikan Nasional Dalam Pusaran Kekuasaan, 2009. 283).

Dilihat dari berbagai pandangan diatas dapat dikatakan bahwa menejemen pendidikan adalah suatu proses perencanaan, pengorganisasian, pelaksanaan, dan pengawasan dalam mengelola sumber daya yang berupa manusia, keuangan, sarana dan prasarana, metode, waktu dan informasi untuk mencapai tujuan secara efektif dan efesien dalam bidang pendidikan.

\section{Ruang lingkup Manajemen Pendidikan}

Ruang lingkup atau garapan manajemen pendidikan menurut Sutisna (1985:16-20) terdiri atas: (1) manajemen merupakan koordinasi kegiatan dalam organisasi pendidikan, (2) manajemen merupakan alat untuk tnengenai tujuan organisasi pendidikan, (3) manajemen menyertakan banyak orang dalam proses pendidikan seperti: peserta didik, guru, pegawai tata usaha, dan orang tua murid, dan (4) partisipasi guru dan orang lain dalam organisasi pendidikan.

Selanjutnua Sutisna (1995:30-31) menambahkan bahwa bidang garapan sekolah antara lain sebagai berikut.

a. Pengajaran dan kurikulum meliputi: Mempersiapkan perumusan, tujuan-tujuan kurikulum, mempersiapkan penentuan isi dan organisasi kurikulum, menghubungkan kurikulum, mempersiapkan bahan, sumber, dan perlengkapan bagi program pengajaran, mempersiapkan program supervise pengajaran, mempersiapkan program pendidikan dalam jabatan bagi para guru.

b. Perhatian terhadap murid meliputi: Merintis dan memelihara sistem penghitungan dan kehadiran murid, mempersiapkan program orientasi bagi para murid, Mempersiapkan program bimbingan dan penyuluhan, mempersiapkan pelayanan kesehatan, mempersiapkan pelayanan administrasi murid, mempersiapkan pelayanan informasi tentang pekerjaan dan pendidikan, mempersiapkan pelayanan penempatan pekerja dan pelayanan lanjutan bagi murid, mengatur prosedur penilaian dan interpretasi pertumbuhan murid secara konstinue, mengatur tata disiplin murid, mengembangkan dan mengkoordinasikan program kegiatan murid.

c. Kepemimpinan masyarakat sekolah, yaitu membantu menciptakan kesempatan bagi masyarakat untuk mengenal komposisinya, melakukan perbaikan melalui 
penggunaan sumber-sumber alami dan manusia, menentukan pelayananpelayanan pendidikan, membantu pembuatan dan pelaksanaan rencanarencana perbaikan kehidupan masyarakat, menentukan dan membantu jasa yang dapat disediakan oleh sekolah dalam perbaikan masyarakat bersama dan melalui kerjasama dengan lembaga lain, dan memungkinkan penulisan secara kontiniu rencana dan kebijaksanaan yang dapat diterima untuk perbaikan masyarakat, khususnya yang berhubungan dengan jasa yang diberikan oleh sekolah.

d. Personil sekolah yang terdiri dari: mempersiapkan rumusan kebijaksanaan personil, mempersiapkan pengambilan (recrutment) personil, memilih dan menugasi personil, meningkatkan kesejahteraan personil, mengembangkan sistem pencatatan sipil, dan mendorong dan menyediakan kesempatan bagi pertumbuhan propesional personil.

e. Gedung sekolah yang terdiri dari: menentukan kebutuhan akan fasilitas fisik sekolah dan sumber-sumber yang dapat ikerahkan untuk memenuhi kebutuhan itu, Menyusun rencana yang konprehensif bagi pertumbuhan dan peningkatan fasilitas fisik sekolah.

melaksanakan rencana-rencana bagai pertumbuhan dan peningkatan fisik sekolah, menyusun program pengeiolaan dan pemeliharaan fasilitas fisik sekolah yang efisien.

f. Organisasi dan struktur yang terdiri dari: pembangunan hubungan kerja dengan lembaga-lembaga setempat untuk menyediakan pelayanan yang diperlukan oleh sistem sekolah, bekerja dengan Dewan Pendidikan dalam merumuskan kebijakan dan rencana-rencana sekolah, menugasi unit-unit operasional yang sesuai pada sistem sekolah, mengembangkan organisasi personil untuk melaksanakan tujuan-tujuan program sekolah, mengatur kelompok-kelompok profesional dan orang-orang yang bukan ahli guna pertisipasi dalam perencanaan pendidikan dan kegiatan pendidikan dan mengatur kelompok-kelompok profesional dan orang-orang yang bukan ahli guna pertisipasi dalam perencanaan pendidikan dan kegiatan pendidikan lainnya.

g. Keuangan sekolah dan tata usaha yang terdiri dari: Mengatur personil tata usaha, menentukan sumber keuangan sekolah, mengatur gaji personil, Mempersiapkan anggaran pembiayaan sekolah, mengelola pembelanjaan modal dan penyelesaian piutang, mengelola pembelian sekolah, mempertanggung jawabkan keuangan sekolah

mempertanggung jawabkan harta kekayaan sekolah, menyediakan program asumsi sekolah dan menyediakan sistempertanggung jawaban intern.

\section{Tujuan Dan Manfaat Manajemen Pendidikan}

Adapun tujuan dan mamfaat manajemen pendidikan sebagaimana dijelaskan oleh Ara Hidayat dan Imam Machali dalam Pengelolaan Pendidikan (Ara Hidayat dan Imam Machali 2015: 15-16), antara lain:

a. Terwujudnya suasana belajar dan proses pembelajaran yang aktif, inovatif, kreatif dan menyenangkan

b. Terciptanya peserta didik yang aktif mengembangkan potensi dirinya untuk memiliki kekuatan spiritual keagamaan, pengendalian diri, kepribadian, kecerdasan, akhlak yang mulia serta keterampilan.

c. Terpenuhinya salahsatu dari 4 konpetensi tenaga pendidik dan kependidikan.

d. Tercapainya tujuan pendidikan secara efektif dan efesien. 
e. Terbekalinya tenaga kependidikan dengan teori tentang proses dan tugas administrasi kependidikan.

f. Teratasinya masalah mutu pendidikan.

\section{Manajemen Pendidikan dalam otonomi Daerah.}

Pada era otonomi daerah sekarang ini dituntut adanya manajemen pendidikan yang cocok untuk setiap daerah, dikarenakan tiap daerah mimiliki karesteristik tersendiri dalam hal budaya dan adat istiadat. Bila kita kembali pada masa Orde Baru manajemen pendidikan bisa dikatakan choes karena segala sesesuatu berbentuk sentralistik dan tidak mendukung sama sekali atonomi daerah. Sebagai perbandingan bisa dilihat dari pemisahan wewenang pemerintah daerah yang terbatas hanya sekeloh dasar. Begitu juga dengan adanya dualisme penyelenggaraan dan pengelolaan pendidikan oleh kementerian Agama dan Kementerian Pendidikan, tentu situasi ini mempengaruhi terhadap peninkatan kualitas pendidikan khususnya pendidikan agama.

Dalam Undang-Undang No. 22 tahun 1999, urusan pendidikan diserahkan kepada daerah. ( H.A.R Tilar. Kekuasaan dan Pendidikan; Manajemen Pendidikan Nasioanal Dalam Pusaran Kekuasaan, 2009. 295). Ini menunjukan bahwa urusan pendidikan diserahkan kepada daerah dan daerah memiliki wewenang penuh dalam mengatur dan mengelola pendidikan yang ada di daerahnya, apakah ia pendidikan dasar maupun ke perguruan tinggi. Kendatipun demikian apakah benar pelaksanaannya sesuai dengan amanah undang-undang? Justru yang terjadi adalah sebaliknya. Masalah ini muncul terutama pada pendidikan tinggi terus beranggapan bahwa pemerintah daerah tidak ada wewenang dan mempunyai hak terhadap menajemen pendidikan tinggi, sehingga daerah tidak memperdulikan sama sekali terhadap keberlangsungan pendidikan tinggi. seharusnya daerah harus paham betul dengan adanya otonomi daerah maka otonomi pendidikan menjadi sebuah keniscayaan bagi daerah.

\section{Pengaruh Politik dalam Administrasi Pendidikan}

Besar dan luasnya otonomi di bidang penyelenggaraan pendidikan akan tergantung kepada sistem politik dalam memberikan keleluasaan dan kebebasan, sekalipun demikian keleluasaan itu diberikan tidak dapat diartikan sebagai pemberian kebebasan mutlak tanpa mempertimbangkan kepentingan nasional, sehingga menimbulkan konflik kepentingan antara administrator pendidikan pada tingkat pusat dengan administrator pendidikan di tingkat daerah. Dalam pandangan teori Getzels dalam Oteng Sutisna (1983:287) ini disebut konflik antara dimensi nomotetis dengan dimensi idiografis. Sekalipun menurut pandangan teoritis kedua kepentingan tersebut bisa berdiri sendiri, namun berdasarkan prinsip sistem sebetulnya saling ketergantungan untuk menghasilkan sinergi.

Dalam konsepsi proses manajemen, otonomi daerah sebagai perwujudan pelaksanaan azas desentralisasi dalam penyelenggaraan administrasi dan manajemen pendidikan, pada hakekatnya merupakan penerapan teori division of power and authority dari administrator puncak ke administrator pada tingkat di bawahnya. Karena itu, penerapan desentralisasi manajemen pendidikan tidak selalu harus tergantung pada konstelasi politik, karena desentralisasi manajemen tidaklah sama dengan desentralisasi politik dan tidak pula dipandang sebagai suatu sistem yang berdiri sendiri, karena makna desentralisasi dalam manajemen pendidikan bukan merupakan alternatif pengganti sentralisasi, tetapi keduanya merupakan sub-sub 
sistem dalam kerangka sistem penyelenggaraan pendidikan yang lebih luas dan komprehensif.

Pada UU.No.22 Tahun 1999, mempunyai struktur hirarkhis yang panjang dan bertingkat dari tingkat pusat, propinsi, kabupaten/kota, dan desa. Stratum otonomi dibedakan dalam tiga terminologi sebagaimana dijelaskan di muka, maka terminologi mana yang sepadan bila ketiga struktur tersebut dipadukan, akan tergantung pada bagaimana sistem tersebut dipandang; apakah sebagai total sistem, sub-sistem, komponen, dimensi atau variabel dari sistem wholistik. Jika organisasi pendidikan tingkat pusat dianggap total sistem, posisinya ada pada tingkatan manajemen punjak, tugas pokoknya sudah tentu akan berkaitan dengan terminologi manajemen strategis. Organisasi pendidikan pada tingkat propinsi sebagai sub-sistemnya akan berkenaan dengan terminologi manajemen koordinatif. Organisasi pendidikan pada tingkat kabupaten/kota berada pada tingkatan manajemen operasional. Sedangkan organisasi pendidikan pada tingkatan kelembagaan berada pada tingkatan manajemen taktis.

Undang-undang otonomi daerah memang sudah diberlakukan dan sejumlah kewenangan pemerintah daerah dalam bidang pendidikan telah ditetapkan, termasuk dalam segi pembiayaannya untuk lembaga-lembaga pendidikan yang dikelola pemerintah. Apakah karena undang-undang tersebut proses pendidikan harus senantiasa terombang-ambing, sehingga setiap ganti kebijakan politik, paradigma pendidikan harus dirombak pula? Lantas, apakah paradigma administrasi dan manajemen pendidikan pun harus disesuaikan dengan kebijakan otonomi daerah?

Apabila UU.No.22 Tahun 1999 dilaksanakan secara konsisten, secara teoritis kehendak pasal 31 ayat (1) kemungkinan besar dapat terealisasikan, karena pelayanan pemerintah kepada masyarakat di bidang pendidikan dan pengajaran, rentangnya tidak terlalu jauh. Dengan demikian, peranan praktek administrasi dan manajemen pendidikan akan semakin strategis. Persoalan yang patut diantisipasi dalam praktek manajemen pendidikan ialah apakah pemberian otonomi kepada daerah akan menjamin setiap warga negara memperoleh haknya dalam pendidikan? Apakah dengan pemberian otonomi kepada daerah dapat menjamin peran serta masyarakat dapat meningkat dalam penyelenggaraan pendidikan? Pertanyaan ini bisa dijawab apabila seluruh elemen yang bertanggung jawab terhadap pendidikan baik tingkat pusat dan daerah dan politukus mau memahami dan menafsirkan dan mengamalkan Undang-undang No. 22 tahun 1999, dimana urusan pendidikan diserahkan kepada daerah.

Walaupun begitu luasnya otonomi dalam pendidikan diberikan kepada daerah, tetap harus konsisten dengan konstitusi. Dan walaupun bidang administrasi dan manajemen pendidikan termasuk bidang yang diserahkan dan wajib dilaksanakan oleh daerah, namun perlu adanya ketegasan bidang-bidang garapan apa yang menjadi wewenang daerah. Tampaknya, administrasi dan manajemen aspek-aspek pendidikan yang berkaitan dengan identitas dan integritas bangsa memerlukan standarisasi nasional melalui komitmen politik.

\section{Kesimpulan}

Faktor-faktor yang berpengaruh terhadap pelaksanaan otonomi daerah dalam konteks Teori Perubahan, sebetulnya terletak pada faktor karakteristik kemampuan aparatur pemerintah sebagai pelaksana kebijakan. Bagaimana anggota sistem sosial di lingkungan organisasi dan manajemen pendidikan yang bersangkutan dapat menanggapi gagasan-gagasan pembaharuan tadi. Karena itu, implementasi kebijakan desentralisasi melalui UU.No.22 Tahun 1999, bukan hanya sekedar meredam gerakan reformasi total. 
Selanjutnya dengan adanya otonomi daerah maka sudah pasti perlunya manajemen pendidikan di daerah dalam bingkai otonomi yang mengatur manajemen pendidikan kearah lebih bagus. Bukan berarti pula meninggal kewenangan pusat dan mengatur manejemen sendiri -sendiri sebagaimana kita ketahui setiap daerah berlainan kondisi dan budaya dan potensi alam yang dimilikinya juga berbeda dan manajemen pendidikan akan beragam dan mengarah pada egosektoral. Manajemen pendidikan dalam kerangka otonomi daerah justru akan berkembang karena adanya keberagaman diantara daerah. Dalam hal ini setiap daerah perlu mengembangkan manajemen pendidikannya sesuai dengan kebutuhan daerahnya.

\section{Daftar Pustaka}

Arifin. Ilmu Pendidikan Islam; Tinjauan Teoritis dan Praktis Berdasarkan Pendekatan Interdisipliner. Jakarta: Bumi Aksara, 2008

Hamid, Abdul dan Irham Fahmi. Pengantar Manajemen Strategis. Langsa: Zawiyah Serambi Ilmu Pengetahuan, 2015

Hasballah. Kebijakan Pendidikan; Dalam Perspektif Teori, Aplikasi, dan Kondisi Objektif Pendidikan di Indonesia. Jakarta: Raja Grafindo, 2015

Hidayat, Ara dan Imam Machali. Pengelolaan Pendidikan; Konsep, Prinsip, dan Aplikasi dalam Mengelola Sekolah Madrasah. Yogyakarta: Kaukaba, 2012

Jalal, Fasli dan Dedi Supriadi (Editor), Reformasi Pendidikan dalam Konteks Otonomi Daerah. Yogyakarta: AdiCita Karya Nusa, 2001

Jurnal Pendidikan Islam, Kebijakan Pendidikan Islam. (UIN Sunan Kalijaga Fakultas Tarbiyah, Vol III, Nomor 1 Juni 2014).

Pidarta, Made. Manajemen Pendidikan Indonesia. Jakarta: Rineka Cipta, 2004

Ridhotullah, Subekti dan Muhammad Jauhar. Pengantar Manajemen. Jakarta: Prestasi Pustaka. 2015

Rusman. Manajemen Kurikulum. Jakarta: Raja Grafindo Persada, 2012

Soepardi. Dasar-Dasar Administrasi Pendidikan. Jakarta: P2LPTK, Ditjen Dikti, Depdikbud

Sudjak, Abi. Kepemimpinan Manajer, Eksistensinya Dalam Perilaku Organisasi, ( Jakarta: Pusdiklat Depdikbud, 1990

Suharsaputra, Uhar. Administrasi Pendidikan. Bandung: Refika Aditama, 2013

Sutisna, Oteng. Administrasi Pendidikan: Dasar Teori untuk Praktek professional. Bandung: Angkasa, 1983

Tilar, H., Kekuasaan Dan Pendidikan; Manajemen Pendidikan Nasional Dalam Pusaran Kekuasaan. Jakarta: Rineka Cipta, 2009

Yulis, Rama. Metodologi Pendidikan Agama Islam. Jakarta: Kalam Mulia, 2008 